\title{
LOKALE OPFATTELSER AF DEN KVINDELIGE KROP OG DENS REPRODUKTIVE ROLLE - et eksempel fra Uganda
}

Ideer og teorier om den menneskelige krop kan ses som omhandlende kroppens struktur og funktioner - både eksterne og interne. Helman (1990:11) kategoriserer begreber om kropsbilledet $i$ tre typer; ideer om optimal form og størrelse, ideer om indre strukturer og ideer om, hvordan kroppen fungerer. Disse begreber påvirkes af socio-kulturel baggrund og har vigtige implikationer på individets helbred. Opfattelser af den kvindelige krop og specielt i relation til reproduktion har mere vidtrækkende effekter eller konsekvenser med hensyn til accept eller ikke-accept af biomedicinsk obstetrisk pleje. I Ankole tror kvinder, der følger prænatal kontrol, i almindelighed, at hvis jordemoderen undersøger dem og bekræfter, at mor og foster er ved godt helbred, er der ingen grund til at komme tilbage til hospitalet for at føde under supervision. Da graviditet ikke ses som en sygdom, er kvinder i Ankole forpligtet til at fortsætte med at arbejde hårdt, mens de er gravide, og under selve fødslen foretrækker de at blive hjemme frem for at tage på hospitalet, for hospitalet er for de syge, ikke for den naturlige fødselsproces. I et studium fra Michigan refereret hos Helman (ibid.:25), var det en udbredt opfattelse, at livmoderen er et hult organ, der lukker sig tæt til under graviditeten for at forebygge tab af fosteret, og en kvinde troede, at gravide kvinder ikke kunne pådrage sig kønssygdomme, fordi livmoderen er lukket og bakterier ikke kan komme ind.

Selv om transition gennem livets cyklus er såvel en social som en biologisk proces, har opmærksomheden inden for det medicinske område overvejende været begrænset til den fysiske krop med det resultat, at man har opfattet den subjektive oplevelse af modning og relaterede forandringer i menneskelige relationer som stort set uvæsentlige $\mathrm{i}$ den medicinske diskurs. Denne artikel søger derfor at undersøge opfattelser af den kvindelige krop i relation til menneskelig reproduktion.

\section{Studieområde og metode}

Ankole ligger i den sydvestlige del af Uganda og deles administrativt i distriktet Mbarara mod $\varnothing$ st, Bushenyi i vest og det nyoprettede distrikt Ntungamo i syd. Banyankole ${ }^{1}$ tilh $\varnothing$ - 
rer bantufolkene i Østafrikas interlacustrine region. Området er etnisk delt i bahima pastoralister og bairu agerbrugere. Ankole er et af de områder i Uganda, der har høje fertilitetsrater (8.8 ved folketælling i 1969, 8.8 ved folketælling i 1980 og 8.7 i 1985 (Ntozi \& Kabera 1991:116). Der har også været migration af banyarwanda og naboerne bakiga til området. Indflydelsen fra baganda, en historisk dominerende stamme i det centrale Uganda, mærkes også, specielt i den urbane del af Mbarara by.

Som i de fleste dele af Uganda er ægteskabet nærmest universelt, tidligt, og grundlæggende med henblik på forplantning, og enhver kvinde hævdes gift ved 45-årsalderen. Dette afspejler Banyankoles ønske om at få enhver kvinde gift for at undgå den sociale forlegenhed og det dårlige varsel, som ugifte kvinder menes at påføre deres slægtninge (ibid.:116; Neema 1991). Børns værdi er høj; specielt sønnerne, da de repræsenterer slægtens fremtidige forsikring og kontinuitet, lige som det er deres forpligtelse at understøtte forældrene i alderdommen, at se efter kvæget og at beskytte forældrenes ejendom (Ntozi 1990:436). Distriktspecifikke barselsdødsrater foreligger ikke, men ifølge statistikker fra Kampala city, Ugandas hovedstad, forekommer der 3.5 dødsfald i forbindelse med barsel for hver 1000 fødsler (Kampikaho 1988).

Data til denne artikel er baseret på et studium udført i området i en et-årsperiode fra marts 1992 til marts 1993, hvor der blev anvendt såvel dybdegående kvalitative etnografiske metoder som kvantitativt survey. Survey'et omhandlede 300 kvinder; 100 fra kommunen, 100 fra bahima pastoralister og 100 fra bairu agerbrugere. Denne artikel behandler hovedsageligt materiale indsamlet ved dybdegående interviews og fokusgruppediskussioner blandt kvinder fra bairu-agerbrugere, bahima-pastoralister og fra byområdet. $^{2}$

\section{Bio-sociale kropsaspekter}

Graviditet og fødsel kan i et holistisk perspektiv ses som også omfattende sociale, rituelle og moralske aspekter. I Ankole ses kroppen, omubiri, som både en biologisk og social enhed. Når der her skelnes mellem, hvad der er biologiske, og hvad der er sociale aspekter af kroppen, er det derfor først og fremmest en abstraktion foretaget med henblik på analytiske formål. Min teoretiske tilgang til at forstå kinyankole modellen og opfattelsen af kroppen er at se på det ud fra den bio-sociale ramme (Jordan 1980), hvor fødsel som et fænomen produceres i forening og fleksibilitet af (universel) biologi og (givet) samfund. I sin bio-sociale model understreger hun, at fødslen som bio-social begivenhed på samme tid leder tanken hen på og anerkender såvel den universelle biologiske funktion og den kulturspecifikke sociale matrix, hvori menneskelig biologi er indlejret. På lignende vis identificerer Helman to kroppe; det individuelle krops-selv, som er både fysisk og psykisk og opnås ved fødslen, og også den sociale krop, som er nødvendig for at kunne leve inden for et givet samfund (1990:14).

Der er kroppens biologiske funktion og dens enhed og det socio-kulturelle miljø, inden for hvilket den menneskelige biologi udspiller sig. Banyankoles mange reproduktionsritualer og regler i relation til den kvindelige krop, specielt i tiden omkring graviditet og fødsel, forsyner hver enkelt kvinde med en model for at forstå og fortolke sine egne fysiske og psykiske erfaringer. Dette påvirker atter valg af sted for fødslen, hjælper ved fødslen og mediciner. 


\section{Kroppen som „en sæk“ og „en gryde“}

For at forstå banyankoles opfattelser af den kvindelige krop er det nødvendigt først at se på teorierne om undfangelse, da den markerer begyndelsen til liv og dermed den fysiske krop.

Ifølge nogle kvinder er Gud skaberen af barnet, så mennesker burde end ikke tale om det. Dog mener andre, og især de, som er uddannede og har tilegnet sig de biologiske/ biomedicinske definitioner på undfangelse, at mand møder kvinde, de blander sig, kuterana, via samleje, og både mandlig sperm og kvindeligt æg danner barnet.

Hvis kvinden imidlertid har en særlig lidelse kaldet ekirweire, en svagt defineret lokal sygdom, menes det, at de reproduktive væsker, som blander sig for at danne barnet, konsumeres af denne ekirweire, hvilket forårsager goldhed eller infertilitet. For at forebygge ekirweire er kvinden nødt til at tage lokale urter som omusununu, ekarwe, estim$w a, \mathrm{~m}$. fl. Dette forklarer, hvorfor de fleste banyankole-kvinder indtager temmelig mange afkog af lokale urter under graviditeten, selv når de ikke er syge.

Generelt tror den ældre generation af kvinder, at undfangelsen finder sted i stadier af metamorfose. Ifølge denne overbevisning hældes væske, amaizi, fra manden ind i kvinden, hvor den blander sig med kvindens tilbageholdte blod, for når en kvinde undfanger, ophører menstruationen, og en geléagtig substans formes, der ligner frøæg, amahuri gekikere, der flyder på vand. Denne geléagtige substans begynder at tage form, okutond$w a$, og får den rette varme fra livmoderen, nyinenda, ordret ,mavens mor", hvor barnet vokser. Livmoderen ses dermed som en af de signifikante dele af den kvindelige krop.

Det antages videre, at rygraden begynder at dannes, dernæst vokser sig til en lille fugl, akanyonyi, dernæst til en lille rotte, akabeba, som danner hænder, øjne, ben etc. På dette stadium begynder den at vokse sig ind i sin egen pose og danner en beskyttende seng, og da begynder der at udvikle sig et fuldt udvokset menneskebarn. Den kvindelige krop ses således metaforisk som indeholdende en ,sæk“, der er livmoderen, hvori barnet gror; ifølge denne tro er det, som virkelig får barnet til at gro, moderens blod, som blev tilbageholdt, da menstruationen ophørte ved undfangelsen, sammen med varme dannet af ,sækken“.

Livmoderen betragtes også metaforisk som en ,gryde“, der genererer varme til barnet, og samtidig, når veerne sætter ind, påbegyndes autentisk kogning (,,authentic cooking“, o.a.), og moderen må vente indtil barnet bliver „kogt færdig“, enda kusya, parat til at blive presset ud. Hvis kvinden begynder at presse, før barnet er „kogt og parat“, kan det forårsage dødfødthed.

Denne teori om undfangelse gennem stadier af metamorfose reflekteres også i kinyankole-ideer om troldmænd og -kvinder, som menes at have evner for metamorfose, hvorved de skifter til dyre- eller fugleform og forlader deres jordiske kroppe sovende derhjemme (Ahimbisibwe 1990:14).

Inden for det biomedicinske paradigme er den biologiske reproduktions forløb også delt i stadier, eller trimestre, hvor fosteret på hvert stadium, eller i løbet af hvert trimester, udvikler sig, indtil det bliver fuldt menneskeligt. De tre trimestre markerer fosterets udvikling og vækst i dets interne og eksterne struktur og organer, mens det forandrer form og størrelse.

I mange kulturer afgrænses gravide kvinder som en særlig kategori af personer, omgivet af beskyttende tabuer og skikke; og disse hjælper til i retrospekt at forklare enhver 
fysisk skade eller deformitet i nyfødte børn (Helman 1990:25). I Ankole betragtes en gravid kvinde ikke som syg, men som sårbar over for naturens kræfter, og dette er grunden til, at hun må følge en særlig livsstil under graviditeten, med ritualer og mediciner der forebygger enhver vanskæbne i denne sårbare periode. Hun kan være sårbar over for det, hun ser, for eksempel et menneskes eller et dyrs døde krop, over for det, hun gør, som at dræbe et dyr eller plante sødekartofler, eller over for det, hun spiser, som for eksempel at hun skal afholde sig fra at spise sukkerrør etc.

Den fysiske krop antager dermed på sin vis en anden rolle som social krop påvirket af det socio-kulturelle miljø i lokalsamfundet, og den må overholde visse principper, der er nødvendige for at leve harmonisk i det pågældende samfund.

\section{Fusionsritualet}

Nogle få dage efter nedkomsten må banyankole-ægtepar have rituelt samleje, kaldet okucwa ekizire, der ordret betyder ,,at forkorte barselsperioden“. Som følge af graviditet er den kvindelige krop stadig sårbar i den tidlige efterfødselsperiode, hvorfor dette ritual udføres, for at denne periode kan bringes til ophør, og der ikke længere vil være nogen fare for barn og mor, i tilfælde af at faderen opsøger samleje med andre kvinder. Det menes, at ingen af forældrene, men specielt ikke faderen, må hengive sig til udenomsægteskabeligt samleje, efter at barnet er blevet født, det skal først finde sted med moderen, og derefter er han fri, og ingen skade kan ske. Tidligere studier udført af Ntozi og Kabera (1991) i det samme område fandt, at dette rituelle samleje fandt sted fire dage efter fødslen, mens jeg fandt, at det generelt fandt sted knap tre uger efter fødslen. Seksuelt samkvem med nogen anden kvinde end den hustru, der har født, undgås derfor indtil det har fundet sted med denne hustru. Efterfødselssamlejets ritual tjener til at indstille enhver fare for moder og barn og afspejler dermed den fysiske krops farer ved hjælp af socio-kulturelle forklaringer.

\section{Den „inverterede krop“}

Set fra et biomedicinsk synspunkt vides der kun lidt om den kvindelige krops indre, specielt under graviditet, blandt de fleste kvinder i Ankole, bortset fra de kvinder, som har gået i skole og studeret kroppens biologiske anatomi. De indre kropsdele er hverken godt forstået, skelnet, karakteriseret, klassificeret eller tilskrevet deres biologiske funktioner. Helman (1990:16) angav, at vigtigheden af ,,inden i kroppen“-billedet er, at det påvirker folks opfattelse og fremstilling af kropslige lidelser og kan påvirke deres reaktioner over for biomedicinsk behandling. Et eksempel fra Ankole er de kropslige symptomer eller besvær i ekirweire-sygdommen, hvor hver kvinde har sin egen måde at beskrive, hvorledes hun føler, når hun lider af sygdommen. Nogle vil sige, at de føler sig forstoppede, andre føler akutte gennemborende smerter, mens andre føler en brændende virkning.

I Ankole menes det, at fosteret må spise af amabere gomunda, ,,indvendige bryster“ magen til de ydre bryster, men mindre. Denne formodning underst $\varnothing$ ttes, mener de, af esoosi' erne, den nyfødtes første afføring, der er blødere og mørkere end den afføring, der 
produceres, efter at barnet får mælk fra de udvendige bryster. Det menes også, at når en ammende mor bliver gravid og fortsætter med at amme barnet, vil det blive sygt af eiyoshe, en sygdom, der giver barnet feber og diarré og får det til at blive gulligt og svagt. Biomedicinsk associeres denne sygdom med fejlernæring, da dens beskrivelse nærmer sig beskrivelsen af kwashiorkor, en proteinmangelsygdom hos børn. Denne tilstand hævdes at opstå, fordi mælkeproduktionssystemet har forandret sig; den mælk, der nu produceres er for det nye barn, fosteret, og ikke passende for det ældre barn. Den ,gamle mælk“ er hård og tyk og ikke god for fosteret, hvorfor kroppen producerer let og vandet ny mælk, der egner sig til fosteret. Den ,gamle mælk“ har nu skiftet indhold og er transformeret om til ,ny mælk“, der gør det diende barn syg af eiyoshe. Eiyoshe menes også at være delvist forårsaget af varmen fra den ammende mors graviditet. Graviditeten skaber en masse varme, omuriro gwenda, og barnet burde ikke være i nærheden af moderens graviditet. Varme menes at være farligt for barnet og forårsage den gullige, sygelige tilstand $i$ det diende barn.

Ntozi og Kabera (1991) hævdede, at eiyoshe menes at være forårsaget af graviditet i utide, hvilket forurener brystmælken og forårsager diarré. Men ifølge mine indgående diskussioner med kvinder om eiyoshe-sygdommen er det ikke forgiftning af modermælken, der forårsager diarré, men snarere uforgiftet ny mælk, der dannes til det nye foster, der gør det diende barn sygt, fordi mælken forandres specifikt med henblik på det nye barn i livmoderen, og derfor må det diende barn nødvendigvis få diarré. Således forandrer graviditeten mælkens indhold, og den ændrede mælk forårsager diarré i det diende barn; koblet med varmen fra moderen forårsager det alt sammen eiyoshe-sygdommen.

Banyankole mener, at kroppens indre struktur, eller organer, kan helbredes eller behandles udefra. Kvindekroppens indre organer kan kontaktes udefra, selv når der ikke er noget direkte indtag af medicin, så som oral medikation, inhaleringsmidler, indsprøjtninger eller mediciner, der indgnides på kroppens overflade. Det er derfor, at visse forskrifter, så som traditionelle svangerskabsforebyggende midler, bruges på kroppens overflade, som for eksempel at binde bestemte urter i et bælte om livet for at kvinden ikke skal blive gravid, eller at amuletter bæres syet ind i tøjet nærmest ved kroppen. De mener, at medicin båret nær kroppen som et kontaktpunkt kan have en fjern effekt på den indre krop. Selv om banyankole sætter pris på børn, føler de, og specielt de ældre kvinder, et behov for at forhindre undfangelse, når kvinderne har fået den ønskede størrelse familie.

Den ydre krop kan være fedtet og beskidt, og hvis den er det, renses den som regel. Dette bruges også til at beskrive, hvordan den indvendige krop kan være. Den indre krop bliver beskidt ved indtagelse af forskellige slags substanser, som føde og væske. Derfor må den ,renses“ som den ydre krop. Dette er grunden til, at de fleste gravide kvinder i Ankole tager en masse urter som ekyoganyanja med det formål at rense det indre for ,indre olier“, amajuta gomunda, der er farlige for både mor og barn, og som kan forårsage abort eller endda ufrugtbarhed. De synlige ydre kropsdele hjælper til at forklare og beskrive de indre dele af kroppen.

\section{Ærbarhed og fødsel}

Regler om ærbarhed er en af grundene til, at nogle mødre foretrækker at føde alene eller i hjemmet sammen med en slægtning. I Ankole angav kvinder, at mænd ikke burde se en 
fødende kvindes genitalier, selv hvis det er hans hustru. Det er derimod ingen skam for en mor eller svigermor at se sin fødende datters eller svigerdatters genitalier, faktisk assisterer de fleste mødre eller svigermødre deres døtre og svigerdøtre under fødsler. Derimod ville det blive anset for vanærende for en svigermor, der stadig føder børn, hvis hendes genitalier skulle blive set af en af hendes sønners hustruer - baka batabani baawe kukuringura, ,at dine svigerdøtre ser dine kønsdele er en skam“. På basis af ærbarhed følte kvinder det ligeledes krænkende at tage til Mbarara Hospital af frygt for, at medicinstuderende skulle ,lære“ på deres krop.

\section{Den kvindelige krop i fare}

Ifølge det biomedicinske paradigme udgør for tidlige, for sene og for hyppige graviditeter en risiko for moderen. Moderens alder påvirker i stor grad de mulige komplikationer under graviditet og fødsel uanset landets rater for dødelighed ved graviditet og fødsel. Data fra udviklingslandet Venezuela og det udviklede land Wales viser, at i begge tilfælde er der højere dødelighed i aldersgruppen under 20 år og over 35 år; den sikreste periode ligger mellem 20 og 29 år (Mirembe \& Turyasingura 1989:6). Forholdet mellem alder og graviditet udgør derfor grafisk en J-formet kurve, med høj dødelighed for meget unge og ældre kvinder og kvinder, der enten er i deres første graviditet eller har haft mange. Risikoen er imidlertid lav indimellem. Alder ved graviditet, og især meget ung alder, associeres også med dårligt helbred som resultat af tidlig seksuel aktivitet, seksuelt overførte sygdomme, for eksempel gonoré og HIV, uplanlagt graviditet og med komplikationer under graviditet og fødsel, som for eksempel urinvejsfistler, ufrugtbarhed etc. (Turyasingura \& Neema 1993:67).

I kontrast hertil er alder ikke et vigtigt emne blandt banyankole og specielt ikke i den ældre generation. Nogle af de interviewede kvinder kunne ikke huske deres alder. I løbet af mit feltarbejde interviewede jeg en vis kvinde på omkring 50 år, og da jeg spurgte hende, hvad hendes alder var, fortalte hun mig, at hun var i tyverne. Når nogle ikke kender deres alder, hvordan skulle de da kunne fortolke risiko som værende alderspecifik? Dette illustrerer, hvorledes aldersspecifikke risici sjældent erkendes, og i det omfang, hvor risici forbundet med alder faktisk erkendes, opfattes et anderledes mønster end i de biomedicinske opfattelser.

Banyankole udelukker ikke risici ved hyppige børnefødsler, specielt ved højere alder. Dette afspejles i ordsproget nikwembazaara akagwa aharyamwenda, der ordret betyder „det er sådan, jeg føder dem, endte med at dø ved den niende fødsel“. Dette ordsprog udtrykker de risici, der tillægges en erfaren kvinde, som har født normalt uden komplikationer, men dør ved den niende fødsel. Med hensyn til fødsler er det derfor ikke altid erfaring, der er af betydning. Den niende fødsel anses for at være farlig, i betydningen uheldsvanger, som tretten i nogle kulturer anses for at være et uheldigt tal. Risikoen for moderens død ved høj alder erkendes derfor indirekte.

Ægteskab er i denne del af landet tidligt og grundlæggende med henblik på forplantning. Børns værdi er høj, og få kvinder praktiserer svangerskabsforebyggelse. Så snart en kvinde er gift, forventes hun at blive gravid. Derfor forkommer såvel tidlige og hyppige som sene graviditeter. Den gravide kvinde forventes at fortsætte med sine normale arbejdsbyrder, som at grave, bære brænde og vand og almindeligt husarbejde. Den kvinde- 
lige krop bør forblive aktiv under hele graviditeten. Det menes, at en inaktiv krop vil påvirke fødselprocessen, specielt veerne. En krop, som har været inaktiv, vil gøre fosteret dovent, og på tidspunktet for nedkomsten vil det ikke have lyst til at komme ud og forårsager en vanskelig og forlænget fødsel. Dermed er den kvindelige krop i fare, hvis den holdes doven under graviditeten.

Det menes, at graviditet og varme er uforenelige. En gravid kvindes krop bør ikke udsættes for overdreven varme, omuriro; varme forårsager abort, så kolde bade anbefales, specielt tidligt om morgenen og om aftenen, og de menes at være en god balancemekanisme til at afværge uønsket eller overdreven varme. Varme menes også at forhindre undfangelse, $\mathrm{og}$ at bade $\mathrm{i}$ koldt vand menes at holde barnet aktivt, så det ved fødslen kommer hurtigt ud.

Kroppen kan være i fare på grund af de substanser, både fast føde og væsker, som moderen indtager under graviditeten. Visse madvarer bør ikke indtages af en gravid kvinde, fordi de forurener og kan bringe fosteret i fare ved at forårsage, at det bliver født med visse sygdomme. Et godt eksempel er emikwanzi og emiize sygdommene, som i den nyfødte afstedkommer udslet på huden og generel svagelighed. Det er forbudt en gravid kvinde at spise sukkerrør, da fosteret menes at blive født med segmenter og ledafsnit som et sukkerrør; hun bør ikke spise peber, da barnet vil blive født med røde øjne; hun bør ikke spise for meget salt, da barnet vil blive født med udslet på huden. Vordende mødre bør heller ikke spise kylling eller æg. Dette betyder, at gravide kvinder ofte mangler et fødeemne med høj proteinværdi i deres kost, men generelt afsvækkes disse fødevareforbud med tiden, specielt med yngre mødre.

Den kvindelige krop tænkes at være i fare, hvis den gravide kvinde ser eller gør visse ting, som hun ikke formodes at gøre. Hvis hun ser et dødt dyr, som for eksempel en kat, en hund eller en kamæleon, vil hun føde et barn, der ligner disse dyr, og sådan et barn kaldes amahano.

Hvis en gravid kvinde dør, kan hun ikke blive begravet i den samme grav som fosteret, for i kinyankole-kulturen anses et foster for at være et fuldt menneskeligt væsen, og ethvert menneskes afdøde legeme må begraves for sig, for at hele klanen ikke skal gå til grunde efter begravelsen. Fosteret fjernes fra den døde kvinde og begraves separat.

\section{Konklusion}

Forskellige opfattelser af risiko udspringer af forskellige fortolkninger af virkeligheden. I den biomedicinske model vurderes en krop i fare statistisk i forhold til aldersspecifikke forhold, hvorved der gives mulighed for sammenligning over tid og populationer. Banyankole-kvinderne tager deres forholdsregler fra lokalsamfundets forståelse af, hvad der kan gå galt, hvis en vordende mors adfærd er modsat af, hvordan samfundet forventer, at hendes opførsel bør være i denne sårbare periode. Vanheld og misdannelser ved fødslen og dødsfald i forbindelse med børnefødsler forklares således retrospektivt i form af visse reproduktive ritualer, centrale værdier og basale principper, der ikke blev overholdt. Den gravide kvinde vælger ikke alene, om hun skal følge skikken og ritualerne, det er snarere samfundet repræsenteret gennem svigermoderen, der sørger for, at hun overholder dem. For den gravide kvinde er de fleste valg omkring reproduktion langt mere end et individuelt anliggende. Hendes erfaringer, valg, reaktioner og fortolkning af vir- 
keligheden er et udtryk for hendes kulturelle konstruktion. De biologiske aspekter af reproduktion udtrykkes og forklares i overensstemmelse med samfundets socio-kulturelle realiteter.

En række opfattelser og strategier i forbindelse med graviditet og fødsel blandt banyankole kvinderne synes at afvige fra det biomedicinske synspunkt og kan medføre manglende konformitet med biomedicinsk praksis. Ankole-kvinders forståelse af en ,inverteret krop“, fusionsritualer i efterfødselsperioden, regler omkring kropslig ærbarhed og de relaterede opfattelser af risici påvirker imidlertid i en vis forstand den adfærd, hvormed de søger at bevare sundhed, specielt i forbindelse med svangerskabspleje.

Denne artikel har søgt at påvise, hvorledes en kvindes fortolkning af graviditet og fare er i overensstemmelse med hendes kropsopfattelser og afspejler samfundets kulturelle værdier. Tilsvarende har Kaufert og O'Neil (1993:51) fastslået, at udvekslingen mellem lægen og den gravide kvinde til dels handler om forskellen på risiko som en subjektiv oplevelse og risiko som en statistisk konstruktion. I Ankole er kvinders definition af risiko baseret på lokalsamfundet og opnås gennem erfaring. Opfattelsen af den kvindelige krop påvirker den måde, hvorpå kvinder vil handle og reagere på den obstetriske plejes præferencer under graviditet og fødsel i forhold til mediciner (både traditionelle og biomedicinske), fødested (hospital eller hjemme) og type fødselshjælper (alene, slægtning, traditionel fødselshjælper eller biomedicinsk personale). At analysere og forstå den kvindelige krop alene i henseende til dens biologiske formåen og funktioner er at benægte, at den også er en social krop, der arbejder i overensstemmelse med de samfundsmæssigt centrale værdier og paradigmer. Begge aspekter af kroppen bør bringes i overvejelse for at forstå folks opfattelser og fortolkning af virkeligheden med henblik på bedre komplementaritet mellem traditionelle og biomedicinske sfærer, specielt inden for tilvejebringelse og brug af sundhedspleje.

Oversat af Nina Johnsen

\section{Noter}

1 Banyankole angiver den stamme af folk, som lever i området Ankole. Munyankole er entalsformen for personer fra denne stamme (banyankole i flertal). Kinyankole er adjektivformen.

2 At jeg er munyankole og arbejder i min egen kultur var en fordel specielt med hensyn til sproglige færdigheder. Nogle af de kulturelle realiteter blev klarlagt uden vanskelighed, fordi jeg voksede op dér og for en tid var en del af den kultur. Der var imidlertid også problemer, som jeg blev mødt med som indfødt etnograf. Visse af emnerne i forbindelse med graviditet og fødsel syntes ikke at udgøre data for mig, fordi de så ud som „hverdagsliv" eller ,normale fænomener", og de forekom mig ikke at være vigtige, hvorimod en fremmed etnograf mere umiddelbart ville have stillet spørgsmål om disse forhold og noteret dem som relevante data. Omvendt afstedkom mine spørgsmål til tider, at folk undrede sig over min mangel på viden. Hver eneste gang, jeg stillede spørgsmål om forplantning, som for eksempel hvordan et barn vokser, grinede de ad mig og undrede sig over, hvorfor jeg i min alder ikke vidste noget om disse emner. Dette ville nok have været anderledes for en fremmed forskers vedkommende, om hvem de ville tænke, at hun har en anderledes forståelse af forplantning, fordi hun er fra en anden kultur, og de ville da være mere end rede til at fortælle hende om deres ideer. 


\section{Litteratur}

Ahimbisibwe, E. K.

1990 Death and Hereafter among Banyankole, Uganda. Journal of African Religion and Philosophy 1(2).

Helman, Cecil

1990 Culture, Health and Illness. London: Butterworth-Heinemann.

Jordan, Birgitte

1980 Birth in Four Cultures. A Crosscultural Investigation of Childbirth in Yucatan, Holland, Sweden and the United States. Montreal: Eden Press Women's Publications.

Kampikaho, A.

1988 Maternal Mortality in Five Kampala Hospitals 1980-1986. Master of Public Health Thesis. Australia: University of Sidney.

Kaufert, P. A. \& J. O'Neil

1993 Analysis of a Dialogue on Risk in Childbirth: Clinicians, Epidemiologists, and Inuit Women. I: S. Lindenbaum \& M. Lock (eds.): Birth and Power, Social Change and the Politics of Reproduction. Berkeley: Westerview.

Neema, Stella

1991 The Proximate Determinants and Their Effect on Fertility in Uganda: A Case of Ankole. M.A. Dissertation in Demography. Kampala: Makerere University.

Ntozi, James Patrick

1990 The Desire for Children in Tropical Africa: The Influence of Relatives on the Fertility Decisions in Ankole, Uganda. Journal of Biosocial Science 22.

Ntozi, J. P. M. \& J. B. Kabera

1991 Family Planning in Rural Uganda: Knowledge and Use of Modern and Traditional Methods in Ankole. Studies in Family Planning 22(2).

Mirembe, F. M. \& G. Turyasingura

1989 Reproductive Health Problems in Uganda. A Paper Presented at the Workshop on Women, Population and Development, at Mbarara Oct. 11-14.

Turyasingura, G. \& S. Neema

1993 The Situation Analysis of Children, Adolescents and Women. An Analytical Paper Presented to UNICEF, August 1993. 
